\title{
FACILITATING INTERCULTURAL COMMUNICATIVE COMPETENCE OF ADULT LEARNERS IN THE CONTEXT OF HIGHER EDUCATION INTERNATIONALISATION
}

\author{
Jan-Urban Sandal ${ }^{1}$, Tetiana Kolenichenko ${ }^{2}$, \\ Anna Verbytska ${ }^{3}$ (corresponding author), Hanna Dyvnych ${ }^{4}$ \\ ${ }^{1}$ Fil. Dr. Jan-U. Sandal Institute, Finstadjordet, Norway \\ ${ }^{2,3,4}$ Chernihiv National University of Technology, Chernihiv, Ukraine \\ anna.verbytska@stu.cn.ua
}

\begin{abstract}
The article is aimed at the assessment of the educational needs of the active older adults, studying their motives to learn English. The hypothesis of the research is that effective formation of the intercultural communicative competence in active older adults is carried out on the basis of the specially developed educational programme "Foreign language (English)" and the communicative-oriented approach in teaching within the framework of lifelong learning. In order to achieve the purpose of the research, a set of scientific methods was used: analysis, synthesis, comparing, generalisation, questioning, testing and interviewing. Respondents were 64 active older adults who were the students of the Centre of education and social activity for elderly people "Second Youth". The majority of respondents $(51 \%)$ showed the increasing level of intercultural communicative competence after the completion of the English language course for ten months. The application of the suggested in the article model will improve the level of English competence, the motivation for learning English, the ability to communicate and interact in the intercultural environment, formation of positive and tolerant perception of intercultural features, the general level of self-confidence, as well as satisfaction of the need for extending communication with other people.
\end{abstract}

Keywords: English language communicative competence; lifelong learning; internationalisation; communicative-oriented approach; motivation; needs assessment.

\section{Introduction}

The knowledge-based society and globalisation challenges influence the necessity to improve people`s skills and competences during the whole life (Colardyn \& Bjornavold, 2004). The European approach of lifelong learning includes the wide range of educational forms (formal, informal and non-formal) and acquiring of skills, knowledge, attitudes and behaviours in everyday life (Dunn, 2003). Adult education is a core component of lifelong learning. It ensures that all adults participate in their societies and labour market. Adult learning and education involves sustained activities and processes of acquiring, recognising, exchanging, and adapting capabilities (UNESCO, 2009).

Using communicative-oriented approach in teaching English facilitates receiving and expanding knowledge about the language as a system, as well as the culture of the country whose language is studied, its history, literature, painting, music, customs, traditions etc. The importance of using the principle of communicativeness by the teacher involves the construction of a process of teaching a foreign language as a model of the process of real communication, which is relevant especially in the old age. After all, due to the issues that exist in the respectful age, the issue of lack of communication is totally important and relevant (Littlewood, 2014).

In the conditions of globalisation, English as a language of international communication is an efficient instrument in multicultural environment. Intercultural communicative competence is important in order to interact with people of different cultural backgrounds. The development of intercultural communicative competence is one of the goals in the field of English language education that helps learners to be interculturally tolerant to the national differences (Byram, 1997; Samovar, Porter \& McDaniel, 2012). Intercultural communicative competence is one of the key competences in the twenty-first century, so one of the main goals in English language training programmes is to educate learners to become intercultural speakers who can build efficient interactions in the international environment (Deardorff, 2012).

The phenomenon of internationalisation of adult education is associated with "practical timeliness", which is expressed, first of all, in thinking, and only then in activity. The internationalisation of adult education is determined by the "setting" of an individual to coexist, interact and engage in a common cultural environment beyond the boundaries of one state (Bork, 2001).

In modern conditions, Ukraine faces many challenges due to the transformational processes taking place in the country. One of the challenges is the creation of conditions for lifelong learning, namely ensuring

Sandal, J.-U., Kolenichenko, T., Verbytska, A., \& Dyvnych, H. (2019). Facilitating intercultural communicative competence of adult learners in the context of higher education internationalization. Advanced Education, 12, 87-93. DOI: 10.20535/2410-8286.169313 
people of all ages equal and open access to quality education. Demographics show that elderly people are the growing population, not only in Ukraine, but worldwide (Eurostat, 2017). In the context of current social changes, digitalisation and globalisation processes elderly people are socially excluded and not integrated into the modern world. Moreover, this category of people is limited in the access to educational, information, social and cultural services. In particular, practices for developing intercultural communicative competence of adult learners are not widespread. Therefore the development of the particular model of the formation of intercultural communicative competence of adult learners in the context of higher education internationalisation is urgent.

\section{Literature review}

The interest to the topic of language learning in the third age dates back to the 1970s (Kalfus, 1977), but first studies were not focused on the individual differences in older adults' ability to acquire a new language. Further case studies, surveys and interviews (Swain \& Lapkin, 2011; Lenet et al., 2011; Ware et al., 2017) compared young adults with older adults. The advantages of studying foreign languages in older adults from the point of view of 'cognitive reserve', as well as language learning strategies to attain both general language proficiency and literacy skills were researched by European and American authors (Antoniou et al., 2013; Bialystok et al., 2016). In the context of our research, we consider that it is important to focus on socio-affective aspects of English language competence formation in the third age: its influence on changes in lifestyle, learning motives, well-being, self-esteem, general communicative skills and identification of a person in a third age (Pfenninger \& Polz, 2018). As for the effect of motivation among elderly people, a lack of self-confidence in this age period is highlighted (Andrew, 2012). Some scholars proved that English classes increase the motivation of the elderly to continue their education and general level of their well-being (Ware et al., 2017).

The studies (Groombridge, 1998; Glendenning, 1995; Swindell \& Thompson, 1995) reveal the benefits of the activity of educational institutions for the elderly. Actually, such educational institutions help the people in the third age as long as possible to remain integrated into society and actively influence the formation of their social environment, promoting their intellectual and spiritual development. Our research is based on previous work of the centre of social activity as the leading technology of social work with the adults, methodology for assessing the needs of the elderly and methods of social adaptation and integration of older people into public life (Kolenichenko, 2015).

Moss \& Ross-Feldman studied how adults`communicative competence develops in a second language as well as an influence of different factors such as age, anxiety, and motivation on the foreign language learning (Moss \& Ross-Feldman, 2003). In the research (Littlewood, 2014; Richards \& Rodgers, 2001) the communicative-oriented approach in English teaching aimed at the development of communicative competence is promoted as suitable for specific learning situations. Communicative-oriented concept means that language considers social context. It is not only important to learn the linguistic forms but also to understand their potential communicative functions. The students should be able to relate the language forms to appropriate non-linguistic knowledge in order to interpret the specific functional meaning intended by the speaker (Littlewood, 2014).

Thus, most of the existing publications are concentrated on the advantages of studying English languages by older adults with the regard of their psychological changes. In our opinion, attention should also be paid to the comprehensive study of the formation of intercultural communicative competence of elderly people, considering the educational environment and the communicative-oriented approach with a focus on the current internationalisation process.

The aim of this article is to conduct the assessment of the educational needs of the active older adults, study the motives of the elderly to learn English, experimentally research the English language proficiency of the people in the third age after the implementation of the educational programme at the Centre "Second Youth" and develop the model for the formation of intercultural communicative competence of adult learners in the context of higher education internationalisation.

We hypothesise that effective formation of the intercultural communicative competence in active older adults is carried out on the basis of the specially developed educational programme "Foreign language (English)" and the communicative-oriented approach in teaching within the framework of lifelong learning.

\section{Methods}

To achieve the aim of the research, a set of scientific methods was used: analysis, synthesis, comparing, generalisation, questioning, testing and interviewing. 
The research was conducted at the Centre of education and social activity for elderly people "Second Youth" of Chernihiv National University of Technology in two stages:

1) At the first stage of the experimental research (September, 2017) we defined the degree of satisfaction of the needs among the elderly; studied the motives of active older adults to learn English; conducted pre-testing the English language proficiency of active older adults.

2) At the second stage of the experimental research (June, 2018) we tested the English language proficiency of active older adults after the implementation of the educational programme.

In the course of the first stage of the experimental research, the methods of questioning and testing respondents were used. Before assessing the degree of satisfaction of the needs among the elderly, we identified the range of needs that exist in the third age. In determining the degree of satisfaction of the needs among the elderly, evaluation was used as the fundamental technology in social work. Using the evaluation technology, a survey method was used. Using the method of conversation, the motivation of the elderly to learn a foreign language was clarified. To determine the level of proficiency in English, an on-line test an online test developed by the British Council for determining the English language proficiency was used.

Respondents were 64 active older adults (age range was from 60 to 89). All of them were the students of the Centre of education and social activity for elderly people "Second Youth". Among the group of the respondents are persons who use other services at the same time: clients of the Territorial Centre for Provision of Social Services of Desnianskyi Regional in the City of Chernihiv Council (28 persons); participants of the project "Social Integration of Victims of National Socialism, Totalitarian Regimes and Other Elderly People to the Community of Chernihiv", which is being implemented at the Chernihiv National University of Technology (10 persons). The other 26 people are residents of the city of Chernihiv, who do not use the services of the Territorial centres, do not participate in the project activity, these are citizens who, after retirement, spend their time at home, communicating with their family.

The processing of the results of the pedagogical experiment was carried out using the methods of aggregation, as well as descriptive statistical methods (parameters of central tendency, dispersion and correlation). For visual representation of the results, graphical methods were used.

\section{Results}

The first stage of the experimental research showed the following results:

1. Assessment of the educational needs of the active older adults. In assessing the educational needs of the elderly, we have identified the degree of satisfaction of the needs of the elderly in a particular educational field. Unsatisfied needs of the elderly people are: the need for new knowledge of a foreign language (85,6\%); the need for new knowledge in psychology $(65,1 \%)$; the need for new knowledge regarding the rights and responsibilities $(61.8 \%)$; the need for computer literacy skills $(84,3 \%)$; the need for financial literacy (79,3\%); the need to visit groups that support the physical condition of the elderly $(75,3 \%)$; the need to visit cultural centres $(68,6 \%)$; the need for expanding circles of communication with other people, establishing communication with new friends $(87,2 \%)$; the need for self-realisation through engagement with creative activity $(64,5 \%)$ (Fig. 1).

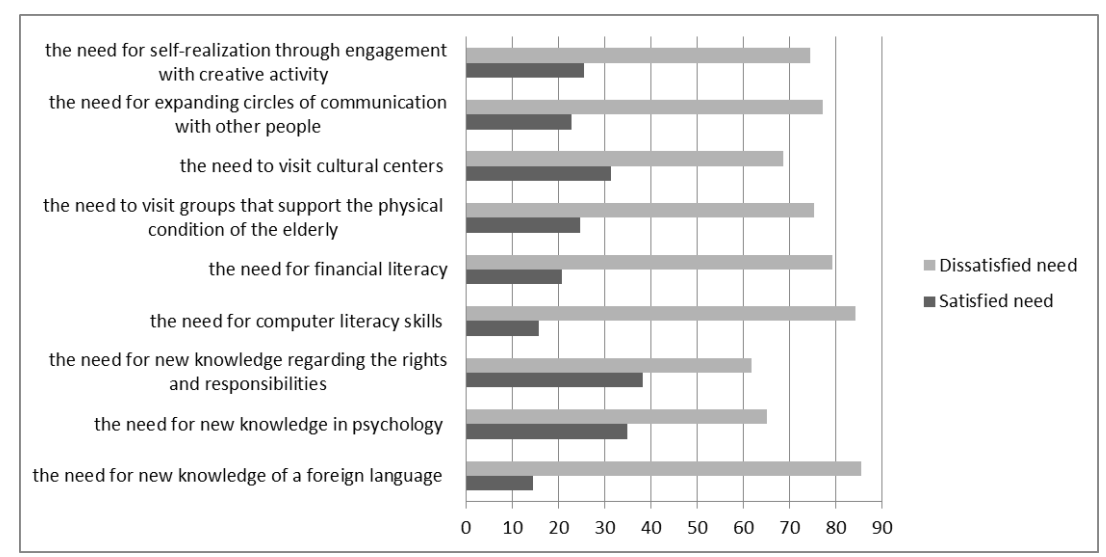

Figure 1. Value of satisfaction of educational needs of the elderly, $\%$

Source: author's development based on a questionnaire conducted in September 2017 at the Centre of education and social activity for elderly people "Second Youth" of Chernihiv National University of Technology

2. The motives of active elderly people to learn English. The main motives were: the desire to read foreign literature $(32,4 \%)$; the desire to read information on the Internet in a foreign language $(21,9 \%)$; the 
desire to be knowledgeable in English (25\%); the ability to communicate with relatives/colleagues/friends abroad $(1,7 \%)$.

3. Testing of English language proficiency of active older adults. According to the results the British Council on-line test (http://www.britishcouncil.org.ua/english/learn-online/test) before starting a course, it was found that there are no participants having high level, $3 \%$ of the group's participants having an average level, and $97 \%$ having low level. The test results suggest that group members in general have a low level of proficiency in English. The educational programme "Foreign language (English)" of training the elderly people lasted one year. After completing the course, the following results were obtained: no participants having a high level of English language proficiency; 54\% of the elderly having an average level; $46 \%$ having low level (Fig. 2).

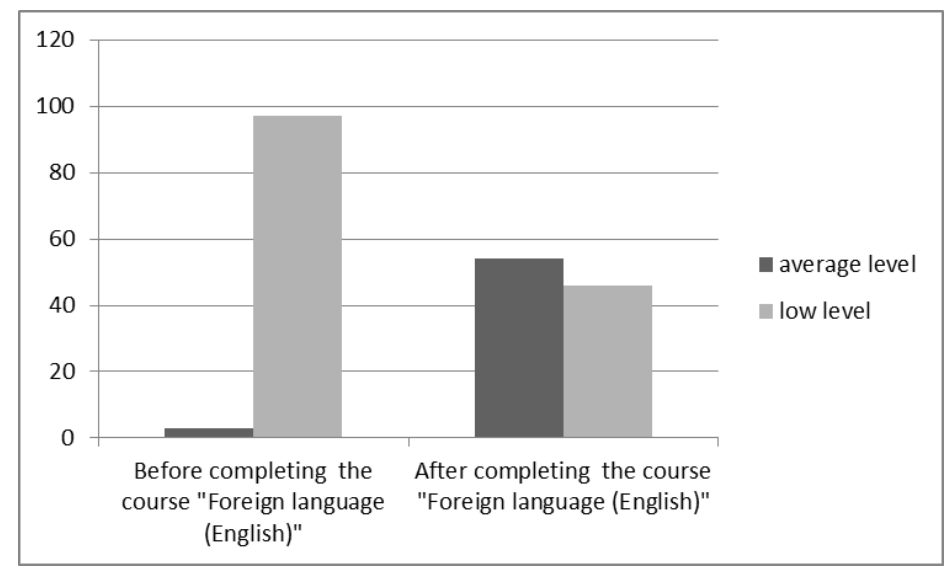

Figure 2. Results of pedagogical experiment, \% (testing of English language proficiency of active older adults)

Source: author's development based the testing conducted in September 2017 and June 2018 at the Centre of education and social activity for elderly people "Second Youth" of Chernihiv National University of Technology

\section{Discussion}

While assessing educational needs, we took into account the following conditions: the conditionality of the results of assessing educational needs of the elderly by the requirements of society and the ability of social work to meet the needs of the elderly through the prism of innovative directions of social work in order to provide social and educational support; the capacity of state and non-state social institutions to meet the needs of the elderly; making effective interaction between a social worker and the elderly (Kolenichenko, 2015). The most visible need of the elderly is the acquiring of new knowledge in a foreign language. Sufficiently highly unsatisfied are the needs in obtaining knowledge of computer and financial literacy. In our opinion, this is due to the transformational processes that are taking place in Ukraine, because we can observe changes that take place in all spheres of public life, in particular political, economic, educational, and challenges that every citizen of our country faces today under the conditions of these processes. Due to its age-old peculiarities, an important need that occurs in the elderly people is the need connected with the support of their physical condition. The need for expanding circles of communication with other people, establishing communication with new friends is important for the elderly people. Quite often, the elderly emphasise the lack of places in the community that would unite elderly people by their interests. This need is closely intertwined with the need to transfer their experience and knowledge to the younger generation.

According to the obtained results of the experimental research, we support the opinion from the International Journal Games for Health that "the main stimulation for older people to learn a foreign language is a challenge, socialisation, fun, providing learning opportunities and escape from daily routine" (Diaz-Orueta et al., 2012). Also, we agree with the idea from the Brain and Language Journal that lifelong learning should be a must because elderly people who keep themselves mentally and physically active are less likely to be depressed. Furthermore, foreign language learning increases self-confidence, enables elderly people to communicate with their peers in foreign countries (Kurdziel et al., 2017).

Thus, the results of the second stage of the experimental research indicate that despite the fact that no participant of the group was found at the high level of English proficiency, there is a general increase in the level of intercultural communicative competence of the elderly after the completion of the English language course for ten months within the framework of the educational programme of the Centre of education and social activity for the elderly "Second Youth" (a half of all students increased the level of English competence from low to average level). 
In recent studies on foreign language learning for older adults, a short-term English training programme was developed. The researcher found out that the course was reasonable and important for this age group. (Ware et al., 2017). The results of the study are caused by the specificity of the psychological development of the elderly. It is commonly known that the ability of the elderly to memorise decreases and their level of attention is lower. In general, the changes taking place at the physiological, psychological and social levels lead to the fact that the learning process of elderly people has its own specificities, namely: the whole teaching material should be adapted for the elderly, the duration of classes should not exceed 45 minutes, in the process of learning the visualisation of the educational material is compulsory. In Frontiers in Communication Journal we found the link to their previous English skills and overall language knowledge for older adult learners rather than cognitive factors (Blumenfeld et al.2017).

The results of the pedagogical experiment proved the article's hypothesis regarding the effectiveness of the use of the communicative-oriented approach to teaching the elderly people English in the conditions of the Centre for education and social activity of the elderly "Second Youth". The results of the experimental research showed the need to develop the model for the formation of the intercultural communicative competence of adult learners. In the basis of the proposed model is the communicative-oriented approach within the framework of lifelong learning (Fig. 3).

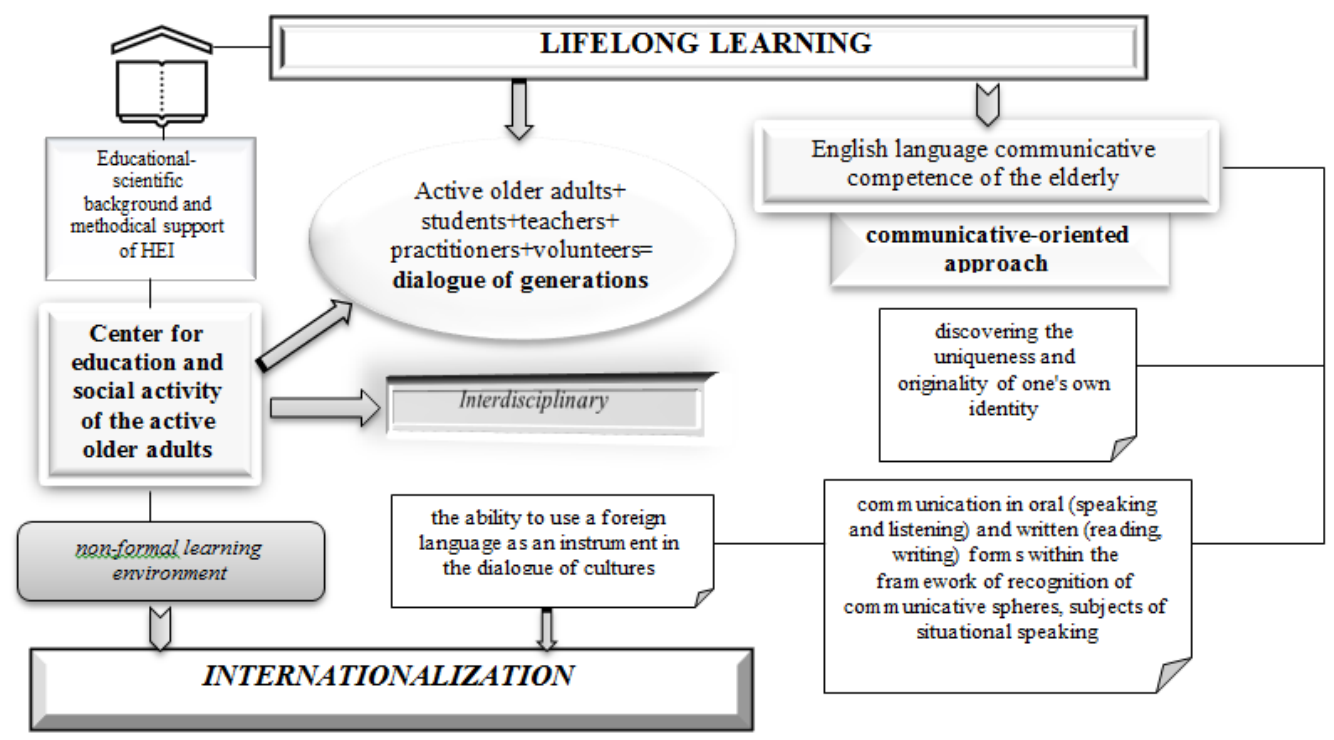

Figure 3. The model for the formation of the intercultural communicative competence of adult learners

Source: authors' development

The concept of education within the Centre for education and social activity of the elderly determines the purpose of training elderly people, which is the formation of the intercultural communicative competence as the ability to use a foreign language in the dialogue of cultures. This includes communication in oral (speaking and listening) and written (reading, writing) forms within the framework of recognition of communicative spheres, subjects of situational speaking. Language, for the elderly, acts as a means of studying the picture of the world and as a key to discovering the uniqueness and originality of one's own identity.

The communicative-oriented approach in the work with the elderly people means that the formation of the communicative competence of the elderly people takes place through person's foreign language communicative activity. In other words, mastering means of communication is aimed at their practical application in the process of communication.

In order to support the interest of the elderly people in the learning process, a teacher uses various tasks, for example: responding exercises (question-answer, replicas, conditional conversation); situational exercises (problematic situations, imaginary situations, role plays); reproductive exercises (retelling, translation, staging); descriptive exercises (description of static scenes, description of real objects); discussion exercises (educational discussion, commentary, situational learning); compositional exercises (oral or written work in a foreign language).

We support the idea formulated by Ware et al. (2017) that any foreign language course should be tailormade to the needs of older people in order to be effective and avoid accompanying factors, such as older 
people's low self-confidence. We agree with the approach proposed by Lytovchenko et al. (2018) on the relation between the education of an adult person and his / her practical life needs, according to which, adult learner is an active participant of the learning process, who plays a leading role in the educating.

The specificity of teaching the English language to elderly people within the proposed model lies in the fact that the teacher needs to form in the elderly a new stereotype of speech communication in addition to the existing one. It is important to note that the success of learning the English language of the elderly depends on the approach to learning selected by the teacher (Garcia, 2017).

Limitations. We consider it appropriate to emphasise that the results of the questionnaire and interview are subjective and are largely tied to psychological factors (the level of self-esteem of respondents).

\section{Conclusions}

Thus, the importance of English as a language of international communication and efficient instrument of multicultural environment is increasing in the current conditions of educational internationalisation. It actualises the necessity of new practices of providing English language communicative competences of active older ("third age") adults. The assessment of the educational needs of the active older adults showed that the most visible need of the elderly is the acquiring new knowledge in a foreign language. The conducted interview allowed finding out the motives of active older adults to learn English: the desire to read foreign literature; the desire to read information on the Internet in a foreign language; the desire to be knowledgeable in English; the ability to communicate with relatives/colleagues/friends abroad. The authors propose the model of the formation of intercultural communicative competence adult learners as an instrument of internationalisation of lifelong learning. The obtained results can be useful for language teachers, facilitators and language specialists who already work, or intend to work with the adult learners. Considering elderly`s educational needs and motivational factors can contribute to the design of specific courses and didactic materials focusing on interests of this group. This paper understands the importance of and tries to increase the studies on English language acquisition in the third age. The further research will investigate the correlation between the motivational factors and language learning strategies involved in the process of studying English as a foreign language in the elderly. Studying older language learners' cognitive and experiential strengths and vulnerabilities in perspective can lead to the development of learning programmes tailored to this target group.

Acknowledgments. This research is carried out within the framework of the scientific project "Integrated Model of Competitive Higher Education in Ukraine under the Quadruple Helix Concept" with the support of the Ministry of Education and Science of Ukraine. The article is the result of the international scientific internship at Fil. Dr. Jan-U. Sandal Institute funded by Fil. Dr. Jan-U. Sandal Institute World Service Fund.

\section{References:}

Andrew, P. (2012). The social construction of age: Adult foreign language learners. Bristol: Multilingual Matters. https://doi.org/10.21832/9781847696151

Antoniou, M., Gunasekera, G. M., \& Wong, P. C. M. (2013). Foreign language training as cognitive therapy for age-related cognitive decline: A hypothesis for future research. Neuroscience and Biobehavioral Reviews, 37(10), $2689-2698$. https://doi.org/10.1016/j.neubiorev.2013.09.004

Bialystok, E., Abutalebi, J., Bak, T. H., Burke, D. M., \& Kroll, J. F. (2016). Aging in two languages: Implications for public health. Ageing Research Reviews, 27, 56-60. https://doi.org/10.1016/j.arr.2016.03.003

Blumenfeld, H. K., Quinzon S. J. R., Alsol C., Riera S. A. (2017). Predictors of Successful Learning in Multilingual Older Adults Acquiring a Majority Language. Frontiers in Communication, 2. Retrivered from: https://www.frontiersin.org/article/10.3389/fcomm.2017.00023. DOI=10.3389/fcomm.2017.00023

Bork, A., (2001). Adult education, lifelong learning, and the future. Campus-Wide Information Systems, 18(5),195-203. https://doi.org/10.1108/EUM0000000006266

Byram, M. (1997). Teaching and assessing intercultural communicative competence. Clevedon: Multilingual Matters.

Colardyn, D., \& Bjornavold, J. (2004). Validation of Formal, Non-Formal and Informal Learning: policy and practices in EU Member States 1. European journal of education, 39(1), 69-89. https://doi.org/10.1111/j.0141-8211.2004.00167.x

Deardorff, D. K., Wit, H. d., Heyl, J. D. \& Adams, T. (2012). The SAGE handbook of international higher education. Thousand Oaks, CA: SAGE Publications, Inc. https://doi.org/10.4135/9781452218397

Diaz-Orueta, U., Facal, D., Nap, H. H., \& Ranga, M. M. (2012). What is the key for older people to show interest in playing digital learning games? Initial qualitative findings from the LEAGE project on a multicultural European sample. Games for Health, 1, 115-123. https://doi.org/10.1089/g4h.2011.0024

Dunn, E. (2003). Life Through Learning; Learning Through Life, The Lifelong Learning Strategy for Scotland: Summary. The Scottish Government. Retrieved 15 February 2019 from http://www.scotland.gov.uk/Resource/Doc/47032/0028820.pdf

Eurostat (2017). Key Figures on Europe. 2017 Edition. https://doi.org/10.2785/21481

Garcia, V. R. M. (2017). Learning English in the elderly: an analysis of motivational factors and language learning strategies. BELTBrazilian English Language Teaching Journal, 8(2), 234-256. https://doi.org/10.15448/2178-3640.2017.2.28264 
Glendenning, F. (1995). Education for older adults: Lifelong learning, empowerment, and social change. In J. F.Nussbaum \& J.Coupland (Eds.), Handbook of communication and aging research (pp.467-490). Mahwah, NJ: Lawrence Erlbaum Associates.

Groombridge, L. (1998). Study of the stages of readiness to adopt exercise and strength training behaviors among adults 65 years and older. Ed.D., Ball State University (James McElhinney).

Kalfus, R. (1977). A new audience for foreign language instruction: The older adult. ADFL Bulletin, 9(2), 49-50. https://doi.org/10.1632/adfl.9.2.49

Kolenichenko, T. I. (2015). Tsentr sotsialnoi aktyvnosti yak providna tekhnolohiia sotsialnoi roboty z liudmy pokhyloho viku [Centre of social activity as a leading technology of social work]. Novi tekhnolohiyi navchannya: naukovo-metodychnyy zbirnyk, 86(2), 61-66. Retrieved 15 February 2019 from https://imzo.gov.ua/diyalnist/naukova-robota/naukovivydannya/zbirnyk-naukovyh-prats-novi-tehnolohiji-navchannya/

Kurdziel, L. B. F., Mantua, J., \& Spencer, R. M. C. (2017). Novel word learning in older adults: a role for sleep? Brain and language, 167, 106-113. https://doi.org/10.1016/j.bandl.2016.05.010

Lenet, A. E., Sanz, C., Lado, B., Howard Jr, J. H., \& Howard, D. V. (2011). Aging, pedagogical conditions, and differential success in SLA: An empirical study. In C. Sanz \& R.P. Leow (Eds.), Implicit and explicit language learning: Conditions, processes, and knowledge in SLA and bilingualism (pp.73-84). Washington, DC: Georgetown University Press.

Littlewood, W. (2014). Communication-oriented language teaching: Where are we now? Where do we go from here? Language Teaching, 47(3), 349-362. https://doi.org/10.1017/s0261444812000134

Lytovchenko, L., Ogienko, O., Sbruieva, A., \& Sotska, H. (2018). Teaching English for specific purposes to adult learners at university: methods that work. Advanced Education, 10, 69-75. https://doi.org/10.20535/2410-8286.149741

McDaniel, E. R., Samovar, L. A., \& Porter, R. E. (2012). Using intercultural communication: The building blocks. In L.A.Samovar, R.E.Porter, \& E. R., McDaniel (Eds.), Intercultural communication: A reader (pp.4-19). Boston: Cengage learning.

Moss, D. \& Ross-Feldman, L. (2003, December). Second language acquisition in adults: From research to practice. Washington, DC: Center for Applied Linguistics. Retrieved 15 February 2019 from http://www.cal.org

Pfenninger, S. E., \& Polz, S. (2018). Foreign language learning in the third age: A pilot feasibility study on cognitive, socio-affective and linguistic drivers and benefits in relation to previous bilingualism of the learner. Journal of the European Second Language Association, 2(1), 1-13. http://doi.org/10.22599/jesla.36

Richards, J., \& Rodgers, T. (2001). Approaches and methods in language teaching (2nd ed.). Cambridge: Cambridge University Press.

Swain, M., \& Lapkin, S. (2011). Languaging as agent and constituent of cognitive change in an older adult: An example. Canadian Journal of Applied Linguistics, 14(1), 104-117. Retrieved 15 February 2019 https://journals.lib.unb.ca/index.php/CJAL/article/view/19869

Swindell, R., \& Thompson, J. (1995). An international perspective on the University of the Third Age. Educational Gerontology: An International Quarterly, 21(5), 429-447. https://doi.org/10.1080/0360127950210505

UNESCO Institute for Lifelong Learning (UIL) (2009). Global report on adult learning and education. UNESCO Institute for Lifelong Learning.

Ware, C. et al. (2017). Maintaining cognitive functioning in healthy seniors with a technology-based foreign language program: A pilot feasibility study. Frontiers in Aging Neuroscience, 9(42), 1-10. https://doi.org/10.3389/fnagi.2017.00042 